\title{
Financial Performance at Heritage Foods Limited
}

\author{
R.Ramamoorthy,Magdalene Peter,Gowtham Assirvad Kumar
}

\begin{abstract}
This paper depicts a Financial Performance venture helpful in both preparerbased and client based starting courses in budgetary bookkeeping. The venture expects understudies to examine slants in corporate execution, to assess corporate budgetary choices, to talk about non-fiscal summary issues that would be critical to potential financial specialists, to analyze two organizations inside an industry, and to make speculation suggestions. [1], [3],[5]
\end{abstract}

The task's prerequisites are completelydetailed on a solitary page, and the undertaking is appropriate to organizations in any industry. The venture requires just restricted presentation in the study hall, is effectively versatile to reflect educator inclinations, and perhaps utilized as either an individual or a gathering task.

This paper incorporates the total task necessity sheet, a reviewing rubric, a group assessment structure, instances of things that understudies may be relied upon to address in responding to the inquiries presented, remarks on the aftereffects of utilizing the venture, and extra proposals for execution. [2 ],[ 4],[6]

Keywords : Financial Performance, financial decision making, introductory accounting project, accounting case.

\section{INTRODUCTION}

The Heritage Milk procedure starts with the chronicle of trans Heritage Milk in the books of essential section. The Milk data coming about because of the Heritage Milk so recorded gets presented in on different Heritage Milk heads in the record. In the record Heritage Milk check is adjusted toward the finish of a Milk period and an outline of all adjusts in the different Milk heads from the record is readied which is known as preliminary equalization from such preliminary adjusts and in the wake of affecting certain modifications thought about important (which is subject to the specific Milk framework pursued by the associations) the budget summaries identifying with the Milk time frame are readied. [8],[10], [12]

\section{OBJECTIVES OF THE STUDY}

\section{PRIMARY OBJECTIVES}

- To study and analyze the financial performance othe Heritage Foods Limited.

- To study the various aspects of financial performance analysis.

\section{SECONDARY OBJECTIVES}

- To get to the elements impacting the budgetary exhibition of the association.

- To discover the presentation of the investigation through proportion examination, pattern examination and similar articulations from recent years.

- To comprehend the general budgetary position of the Heritage Foods Limited. [7],[ 9],[11]

Table:1 Comparative Statement Of Income \& Expenditure Account From 2013 To 2014

\begin{tabular}{|l|l|l|l|l|}
\hline Particulars & 2013 & 2014 & Inc/dec & \%change \\
\hline INCOME & & & & \\
\hline Henitage collection & 11765 & 13180 & 1415 & 12.03 \\
\hline Grants \& donation & 187.8 & 139.3 & -48.50 & -25.83 \\
\hline Interest & 296.6 & 362.4 & 65.8 & 22.18 \\
\hline Other income & 292 & 301.3 & 9.3 & 3.18 \\
\hline TOTAL & 12541.4 & 13983 & 1441.60 & 11.49 \\
\hline EXPENDITURE & & & & \\
\hline Salaries. \& wages & 4372 & 4671 & 299.00 & 6.84 \\
\hline Heritage expenses & 5988 & 6362 & 374 & 6.25 \\
\hline Administration & 1212 & 1314 & 102 & 8.42 \\
\hline Interest & 9.6 & 3.26 & -6.34 & -66.04 \\
\hline TOTAL & 11581.6 & 12350.26 & 769.66 & 6.64 \\
\hline Surplus & 959.8 & 1632.74 & 672.94 & 70.11 \\
\hline Depreciation & 1149 & 1089 & -60.00 & -5.22 \\
\hline \multicolumn{1}{|c|}{ over } & -189.2 & 543.74 & 354.54 & 187.38 \\
\hline Income & & & &
\end{tabular}

Revised Manuscript Received on July 22, 2019.

R.Ramamoorthy*, Department of MBA, Bharath Institute of Higher Education and Research, Tamilnadu, India. Email: ramamoorthy0071@gmail.com

Magdalene Peter*, Department of MBA, Bharath Institute of Higher Education and Research, Tamilnadu, India. Email: magdalene.bsb@gmail.com Gowtham Aasirvad Kumar, Department of MBA, Bharath Institute of Higher Education and Research, Tamilnadu, India. Email: kgowthamaashirwad123@gmail.com

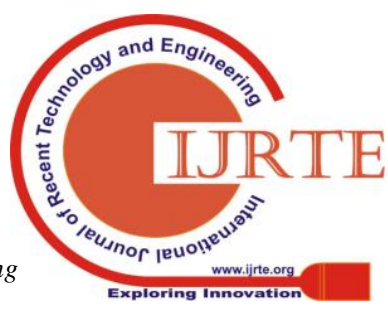


Table:2 Comparative Statement Of Income \& Expenditure Account From 2014 To 2015

\begin{tabular}{|l|l|l|l|l|}
\hline Particulars & 2014 & 2015 & Inc/dec & \%change \\
\hline INCOME & & & & \\
\hline Henitage collection & 13180 & 14459 & 1279 & 9.70 \\
\hline Grants \& donation & 139.3 & 853 & 714 & 512.52 \\
\hline Interest & 362.4 & 473 & 111 & 30.52 \\
\hline Other income & 301.3 & 382 & 81 & 26.78 \\
\hline TOTAL & 13983 & 16167 & 2184 & 15.62 \\
\hline & & & & \\
\hline EXPENDITURE & & & & \\
\hline Salanies. \& wages & 4671 & 5673 & 1002 & 21.45 \\
\hline Henitage expenses & 6362 & 6925 & 563 & 8.85 \\
\hline Administration expenses & 1314 & 1390 & 76 & 5.78 \\
\hline Interest & 3.26 & 35 & 32 & 973.62 \\
\hline TOTAL & 12350.26 & 14023 & 1673 & 13.54 \\
\hline & & & & \\
\hline Surplus & 1632.74 & 2144 & 511 & 31.31 \\
\hline & & & & \\
\hline Depreciation & 1089 & 1116 & 27 & 2.48 \\
\hline & & & & \\
\hline Income & & 1028.00 & 484 & 89.06 \\
\hline
\end{tabular}

Table:3 Trend Analysis Of Income \& Expenditure Account 2013 To 2014

\begin{tabular}{|l|l|l|l|}
\hline Particulars & Trend values & Trend values & Trend values \\
\hline INCONE & & & \\
\hline Henitage collection & $9.68 \%$ & $12.03 \%$ & $9.70 \%$ \\
\hline Grants \& donation & $0.43 \%$ & $-25.83 \%$ & $512.35 \%$ \\
\hline Interest & $1.96 \%$ & $22.18 \%$ & $30.52 \%$ \\
\hline Other income & $-0.44 \%$ & $3.18 \%$ & $26.78 \%$ \\
\hline TOTAL & $0.06 \%$ & $11.49 \%$ & $15.62 \%$ \\
\hline EXPENDITURE & & & \\
\hline Salaries. \& wages & $11.11 \%$ & $6.84 \%$ & $21.45 \%$ \\
\hline Henitage expenses & $12.26 \%$ & $6.25 \%$ & $8.85 \%$ \\
\hline Administration expenses & $0.00 \%$ & $8.42 \%$ & $5.78 \%$ \\
\hline Interest & $-73.33 \%$ & $-66.04 \%$ & $973.62 \%$ \\
\hline T0TAL & $10.12 \%$ & $6.64 \%$ & $13.54 \%$ \\
\hline Surplus before deppreciation(GP) & $-23.70 \%$ & $70.11 \%$ & $31.31 \%$ \\
\hline Depreciation & $-3.36 \%$ & $-5.22 \%$ & $2.48 \%$ \\
\hline Income over expenditure(NP) & $-374.20 \%$ & $-387.39 \%$ & $89.06 \%$ \\
\hline
\end{tabular}

\section{INTERPRETATION}

1. Heritage Collections are rose by $9.70 \%$ in 2015 , but it was $12.03 \%$ in 2014

2. Grants \& Donations are highly increased by $512.35 \%$ in 2015.

3 . Interest and Other income are rose by $30.52 \%$ and $26.78 \%$ in 2015.

4. Over all Income was increased by $15.62 \%$ in 2015 .

5. Salaries \& Wages were increased by $21.45 \%$ in 2015 .

6. Heritage Expenses were increased by $8.85 \%$.

7. Administration Expenses and Interest were increased by $5.78 \%$ in 2015 .

8. Over all Expenditure was increased by $13.54 \%$. Depreciation was increased by $2.48 \%$.
9. Gross Profit and Net Profit was increased by $31.31 \%$ and $89.06 \%$ in 2015

Table:4 Debtors Turn Over Ratio

\begin{tabular}{|l|l|l|l|l|}
\hline Year & $2012-13$ & $2013-14$ & $2014-15$ & $2015-16$ \\
\hline Sales & $31,20,434$ & $41,40,246$ & $59,13,957$ & $72,77,768$ \\
\hline Debtors & $8,25,008$ & $11,26,390$ & $13,78,923$ & $15,98,625$ \\
\hline $\begin{array}{l}\text { Debtors } \\
\text { turnover }\end{array}$ & 3.78 & 3.67 & 4.2 & 4.5 \\
\hline
\end{tabular}

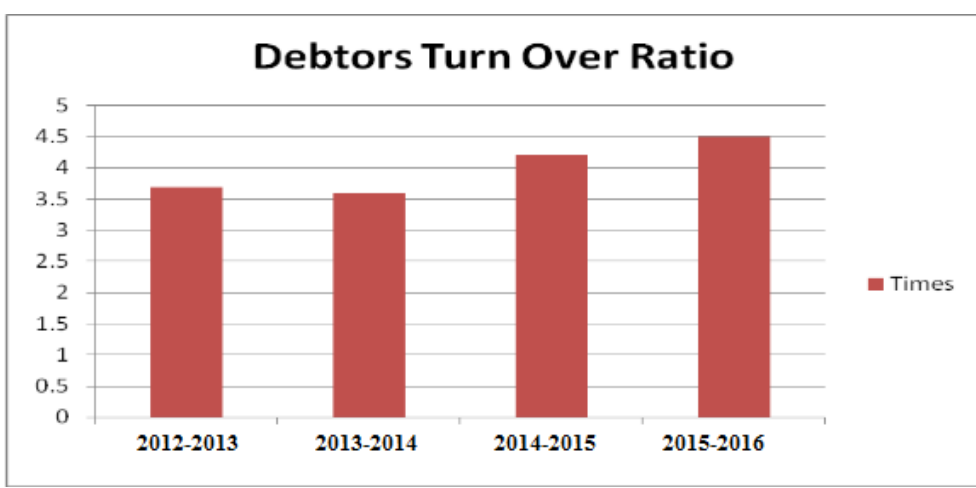

Fig:1 Debtors Turn Over Ratio

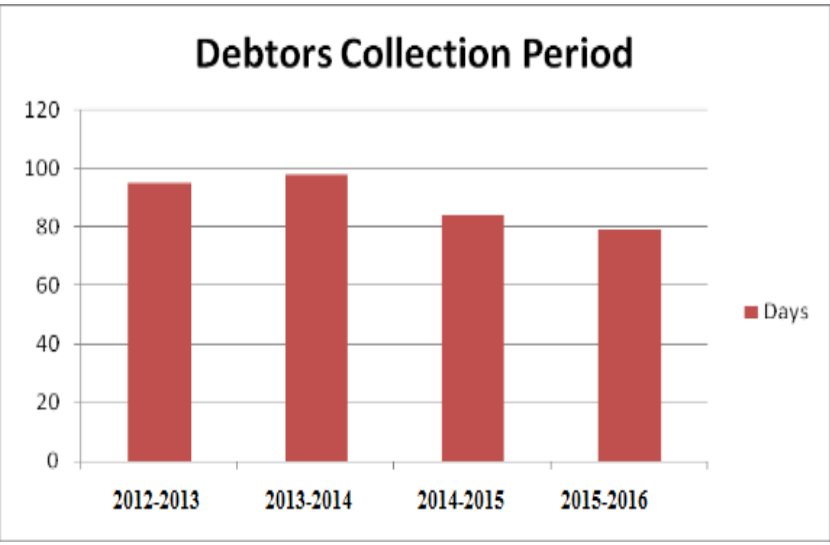

Fig:2 Debtors Collection Period

Table:5

\begin{tabular}{|l|l|l|l|l|}
\hline Year & $2012-13$ & $2013-14$ & $2014-15$ & $2015-16$ \\
\hline Sales & $31,20,434$ & $41,40,246$ & $59,13,957$ & $72,77,768$ \\
\hline Net Asset & $15,39,264$ & $18,56,702$ & $25,25,498$ & $32,92,946$ \\
\hline $\begin{array}{l}\text { Asset turn } \\
\text { over ratio }\end{array}$ & 2.0 & 2.2 & 2.3 & 2.2 \\
\hline
\end{tabular}




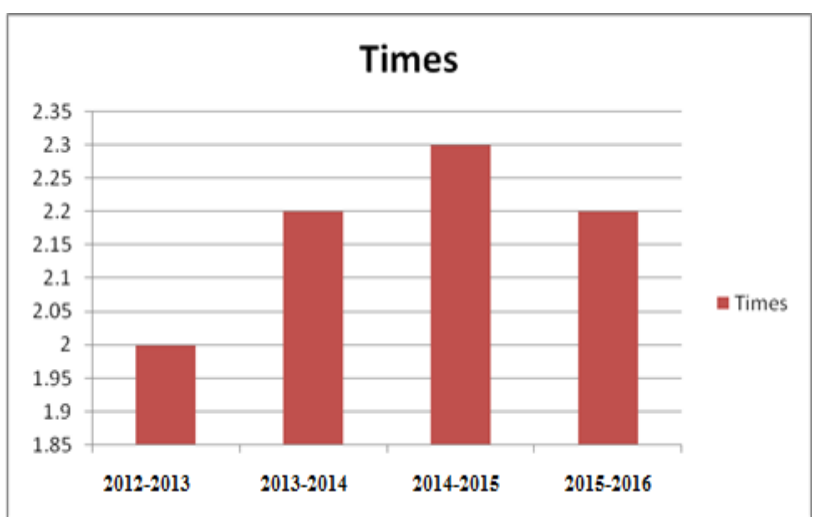

Fig:3

\section{RESULTS}

1. The significant discoveries of the investigation are as per the following.

2. Money extent of the association is poor from now on they will find issue of liquidity position. [13], [15] , [ 17]

3. The record holder's collection time of kec isn't incredible.

4. The expedient extent of Heritage obliged is exhibiting a growing example and it is furthermore underneath the standard extent 1:1.

5. The current extent of Heritage limited isn't satisfy HeritageMilk

6. But it is underneath the standard extent for instance $2: 1$. [14],[ 16], [18]

7. Debt worth extent of the association is far underneath the standard. They have not utilized the ability of getting for the commitments.

8. In the Heritage limited the leasers are paid right away.

9. The association keeps up a co-action among the staff part and the administrators.

10. On an ordinary all together various extents are commonplace.

11. As per solicitation given by the customer supply make HeritageMilk things to them at impeccable time and at right HeritageMilk.

\section{DISCUSSION}

1) Organization should endeavor to keep up its present extent at the standard 2:1. [31],[33],[32]

2) The association should decrease its cost of age through grasping new advancement. It will grow the arrangements.
3) The kec's ordinary social occasion period is high. For avoiding the association should take genuine techniques to assemble the money from borrowers.

4) Company should endeavor to diminish its credit bargains through cash refund at the period of offers. It will meets the present duty.

5) Company is proposed to keep up satisfactory proportion of cash and bank evening out to pay its lively liabilities, which will construct its credit worth and liberality.

6) The association is in hardship on account of overpowering interest weight to avoid this the association should plan to gathering of offer capital in the business.

7) The association should lead step by step social events for central orchestrating, material organization office, and creation office towards undertakings of the association.

8) The association should lead month to month social occasions to knowing its presentation. If the introduction isn't HeritageMilk, by then it will takes essential decisions.

\section{CONCLUSION}

Monetary reports accept critical employment in giving HeritageMilk and figures to the pioneers. Likewise extents will HeritageMilk as assessment pack in the hands of budgetary agent. These extent will bolster us and in reacting to the fundamental request like why, how, what of these declarations. [19],[21],[23]

By and by a days financial outline are particularly in idea for essential initiative. In picking what to do and what not to do they are required to inspect the data as indicated by their essential. Thusly in our endeavor we endeavor to give brief chart of extent assessment (i.e., how to analyze the Heritage Milk and figures given in the financial reports) structure the purpose all things considered. [20],[22], [24]

All through my endeavor I have inspected association's money related position and upsides and drawbacks of the condition and we have also interpreted the data. Despite some limitation we endeavor to separate and interpreted the Heritage Milk and figures with Heritage Milk. [25],[27],[29]

In perspective on the assessment and interpretation I endeavored to give my disclosures and proposition for the association as per my best learning. [26],[28],[30]At long last task truly causes us in knowing the Heritage Milk things of the corporate world. Truly I appreciated this task work in its genuine soul.

\section{REFERENCES}

1. G BharthVajan R., Ramachandran S.,Psychographic dimensions of training,2016,International Journal of Pharmacy and Technology,V-8,I-4,P-23727-23729

2. Balakrishnan P., Bharthvajan R.,A study on human resource planning in hospitals in Chennai City,2014,International Journal of Applied Engineering Research,V-9,I-22,P-7503-7507

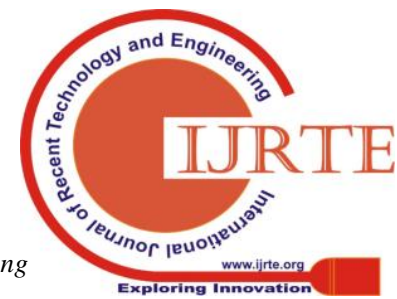


Financial Performance at Heritage Foods Limited

3. Priyadarsini P., Bharthvajan R.,Role of emotional intelligence training programme in reducing the stress of the nurses,2014,International Journal of Applied Engineering Research,V-9,I-22,P-7411-7421

4. Kerinab Beenu G., Bharthvajan R.,Empirical analysis on the cosmetic buying behavior of young women in South India,2014,International Journal of Applied Engineering Research,V-9,I-22,P-7361-7366

5. Balakrishnan P., Bharthvajan R.,Whistling in the wind,2014,International Journal of Applied Engineering Research,V-9,I-22,P-7586-7593

6. Krishnan B., Peter M.,Health hazards of Indian Bpo employee-an alarming issue,2014,International Journal of Applied Engineering Research,V-9,I-22,P-7336-7341

7. Kerinab Beenu G.H., Peter M.,Role of insurance in economic development,2014,International Journal of Applied Engineering Research,V-9,I-22,P-7532-7539

8. Balakrishnan P., Peter M., Priyadarsini P.,Efficiency of safety measures for wellbeing of employees in manufacturing industry,2014,International Journal of Applied Engineering Research,V-9,I-22,P-7376-7382

9. Anbarasi M., Praveen Kumar S.,Online sales promotions of herbal products and its effectiveness towards tanisha.com,2019,Indian Journal of Public Health Research and Development,V-10,I-1,P-195-200

10. Anbarasi M., Praveen Kumar S.,Various online marketing and promotions strategies to improve the validation towards the organic products in the pharmaceutical sectors,2019,Indian Journal of Public Health Research and Development,V-10,I-1,P-263-269

11. Loganathan R., Praveen Kumar S.,Grievance handling a key factor for solving issues of employees in an organization,2014,International Journal of Applied Engineering Research,V-9,I-22,P-7483-7491

12. Loganathan R., Praveen Kumar S.,Study on preference of private label brands in super and Hypermarkets,2014,International Journal of Applied Engineering Research,V-9,I-22,P-7327-7335

13. Smitha M., Praveen Kumar S.,Understanding stress and its managementamong the nurses in Chennai city,2014,International Journal of Applied Engineering Research,V-9,I-22,P-7560-7565

14. Kerinab Beenu G.H., Praveen Kumar S.,A study on the investment behavior of Chennai investors in mutual fund schemes,2014,International Journal of Applied Engineering Research,V-9,I-22,P-7520-7525

15. Loganathan R., Praveen Kumar S.,Retention strategies key for organizational productivity,2014,International Journal of Applied Engineering Research,V-9,I-22,P-7443-7447

16. Pavithra J., Ganesan M., Brindha G.,State wise analysis of microfinance sector in India,2016,International Journal of Pharmacy and Technology,V-8,I-4,P-23417-23432

17. Pavithra J., Ganesan M.,A comparative study on microfinance in India and abroad,2016,International Journal of Applied Business and Economic Research,V-14,I-8,P-5471-5476

18. Pavithra J., Ganesan M.,A study on awareness and impact of micro-financial schemes,2016,International Journal of Applied Business and Economic Research,V-14,I-8,P-5449-5460

19. Senthilmurugan P., Pavithra J.,Consumer preference towards organised retailing with reference to Big Bazaar,2014,International Journal of Applied Engineering Research,V-9,I-22,P-7469-7475

20. Senthilmurugan P., Pavithra J.,Implication of social media marketing in growing healthcare industry,2014,International Journal of Applied Engineering Research,V-9,I-22,P-7448-7456

21. Loganathan R., Pavithra J.,Consumer perception towards private label brand over other brands in super markets and hypermarkets,2014,International Journal of Applied Engineering Research,V-9,I-22,P-7355-7360

22. Kerinab Beenu G., Pavithra J.,Tradeâ€"off between liquidity and profitability in logistics industry,2014,International Journal of Applied Engineering Research,V-9,I-22,P-7398-7401

23. Kerinab Beenu G., Pavithra J.,A study on the prospective consumerâ€ $€^{\mathbf{T M}_{\mathrm{S}}}$ perception towards utility cars in Chennai city,2014,International Journal of Applied Engineering Research,V-9,I-22,P-7526-7531

24. Pavithra J., Dilli Babu P., Ambuli T.V.,A study on budgetary control at Maruti Service Masters, Chennai,2014,International Journal of Applied Business and Economic Research,V-12,I-2,P-151-161

25. Pavithra J., Dilli Babu P., Ambuli T.V.,A study on customer satisfaction of retro Garments Pvt Ltd, Chennai,2014,International Journal of Applied Business and Economic Research,V-12,I-2,P-381-391

26. Kerinab Beenu G.H., Pavithra J., Senthilmurugan P.,A study on the influence of promotional activities for TATA ARIA among consumers in Chennai,2014,International Journal of Applied Engineering Research,V-9,I-22,P-7572-7578

27. Vijayaragavan S.P.,An investigative expert that's general FBG sensors, International Journal of Mechanical Engineering and Technology,V-8,I-8,PP-1500-1505,Y-2017

28. Vijayaragavan S.P.,Equalization routing protocol for Wi-Fi sensor strategy,International Journal of Mechanical Engineering and Technology,V-8,I-8,PP-1662-1666,Y-2017
29. Karthik B., Kiran Kumar T.V.U., Vijayaragavan P., Bharath Kumaran E.,Design of a digital PLL using 0.35 $\hat{\mathrm{I}}^{1 / 4 \mathrm{~m}}$ CMOS technology,Middle East Journal of Scientific Research,V-18,I-12,PP-1803-1806,Y-2013

30. Kanniga E., Selvaramarathnam K., Sundararajan M.,Kandigital bike operating system,Middle - East Journal of Scientific Research, V

31. Jasmin M., Vigneshwaran T., Beulah Hemalatha S.,Design of power aware on chip embedded memory based FSM encoding in FPGA,International Journal of Applied Engineering Research,V-10,I-2,PP-4487-4496,Y-2015

32. Jasmin M.,Optimization techniques for low power VLSI circuits,Middle East Journal of Scientific Research,V-20,I-9,PP-1082-1087,Y-2014

33. Jasmin M., Vigneswaran T.,Fuzzy controller for error control of on - Chip communication,2017 International Conference on Algorithms, Methodology, Models and Applications in Emerging Technologies, ICAMMAET 2017,V-2017-January,I-,PP-1-5,Y-2017

\section{AUTHORS PROFILE}

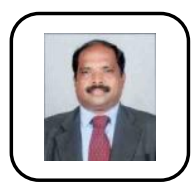

R.Ramamoorthy Assistant Professor ,Department of MBA, Bharath Institute of Higher Education and Research, Tamilnadu, India

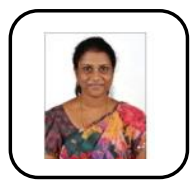

Magdalene Peter Assistant Professor ,Department of MBA, Bharath Institute of Higher Education and Research, Tamilnadu, India

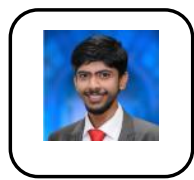

Gowtham Aasirvad Kumar Assistant Professor ,Department of MBA, Bharath Institute of Higher Education and Research, Tamilnadu, India 